\title{
DO ALL SEDENTARY BEHAVIORS AFFECT LIFE SATISFACTION EQUALLY IN STUDENTS AGED 12-16 YEARS?
}

SERÁ QUE TODOS OS COMPORTAMENTOS SEDENTÁRIOS AFETAM IGUALMENTE A SATISFAÇÃO COM A VIDA EM ESTUDANTES COM IDADES ENTRE OS 12 E 16 ANOS? TODAS LAS CONDUCTAS SEDENTARIAS AFECTAN DE LA MISMA MANERA A LA SATISFACCIÓN DE VIDA EN ESTUDIANTES DE 12 A 16 AÑOS

\author{
Alberto Grao Cruces (alberto.grao@uca.es)* \\ Román Nuviala Nuviala (roman.nuvialal@uca.es) ** \\ Mónica Aznar Cebamanos (moaznar@unizar.es ) *** \\ Alberto Nuviala Nuviala (anuvnuv@upo.es) ****
}

\begin{abstract}
Previous studies have proven the importance of life satisfaction for teenage development and its relationship with unhealthy behaviors. However, those that examined the association between sedentary behavior and life satisfaction were limited only to screen time. The aim of the study was examine the association of different sedentary behaviors with life satisfaction in 1897 Spanish students aged 12-16 years. Watching TV, using PC, and homework time, as well as life satisfaction were self-reported using validated questionnaires for these ages. We completed linear and logistic binary regression analyses adjusted by age and gender. The results showed that the time of TV watching and PC use were negatively associated to life satisfaction $(B=-.059$ and $B=-.087$, respectively) while the number of weekly hours devoted to homework was positively associated to life satisfaction ( $B=.052)$. Moreover, the students who devoted greater time to sedentary behaviors in front of a TV or PC had significantly greater risk of low life satisfaction $(O R=$ 1.276 and $\mathrm{OR}=1.317$, respectively). On the contrary, the teenagers who devoted more time to homework showed significantly lower risk of low life satisfaction $(\mathrm{OR}=$.809). These results on Spanish students help
\end{abstract}


to confirm the negative relationship of TV and PC abuse with life satisfaction in teenagers. Our findings also suggest that positive emotional responses during homework completion increase life satisfaction, while negative emotions during this behavior do not significantly damage it. In conclusion, life satisfaction could be improved with less screen time but not all sedentary behaviors affect it equally.

Keywords: Screen time, sedentary lifestyle, happiness, homework.

\section{RESUMO}

Estudos anteriores demonstraram a importância da satisfação com a vida para o desenvolvimento do adolescente e a sua relação com comportamentos pouco saudáveis. No entanto, aqueles que examinaram a associação entre o comportamento sedentário e a satisfação com a vida limitaram-se apenas ao estudo do tempo passado em frente ao ecrã. O objetivo do presente estudo foi examinar a associação de diferentes comportamentos sedentários com a satisfação com a vida, em 1897 estudantes espanhóis com idades entre 12 e 16 anos. Ver televisão (TV), usar o computador pessoal (PC) e o tempo associado à realização dos trabalhos para casa (TPC), bem como a satisfação com a vida foram avaliados através do uso de questionários de auto-perceção validados para essas idades. Foram realizadas análises de regressão binária linear e logística ajustadas à idade e sexo. Os resultados mostraram que o tempo passado em frente à TV e o uso de PC estavam negativamente associados à satisfação com a vida ( $B=-0,059$ e $B=-0,087$, respetivamente), enquanto o número de horas semanais dedicadas à realização dos TPC era positivamente associado à satisfação com a vida ( $B=0,052)$. Além disso, os alunos que passaram mais tempo em comportamento sedentário frente à TV ou PC tiveram um risco significativamente maior de baixa satisfação com a vida ( $\mathrm{OR}=1.276$ e $\mathrm{OR}=1.317$, respetivamente). Em contraste, os adolescentes que passaram mais tempo na realização dos TPC mostraram um risco significativamente menor de baixa satisfação com a vida $(O R=0,809)$. Estes resultados, obtidos em estudantes espanhois, ajudam a confirmar a relação negativa entre o excesso de tempo em frente à TV ou PC com a satisfação com a vida dos adolescentes. Os nossos resultados também sugerem que as respostas emocionais positivas durante a conclusão da tarefa aumentam a satisfação com a vida, enquanto as emoções negativas durante esse mesmo 
comportamento não a danificam significativamente. Em conclusão, a satisfação com a vida poderia ser melhorada com um menor tempo em frente ao ecrã, mas nem todos os comportamentos sedentários afetam a satisfação com a vida da mesma forma.

Palavras-chave: tempo em frente a écrans, comportamentos sedentários, satisfação com a vida, trabalhos de casa.

\section{RESUMEN}

Estudios previos han demostrado la importancia de la satisfacción con la vida para el desarrollo del adolescente y su relación con conductas poco saludables. Sin embargo, aquellos que examinaron la asociación entre el sedentarismo y la satisfacción con la vida se limitaron solo al tiempo de pantalla. El objetivo del estudio fue examinar la asociación de diferentes conductas sedentarias con la satisfacción con la vida en 1897 estudiantes españoles entre los 12 y los 16 años. Ver la televisión, usar el PC y el tiempo de obligaciones escolares, así como la satisfacción con la vida, fueron evaluados mediante el uso de cuestionarios validados para estas edades. Se realizaron análisis de regresión lineal binaria y logística ajustados por edad y sexo. Los resultados mostraron que el tiempo de ver la televisión y el uso del PC se asociaron negativamente con la satisfacción con la vida ( $B=-0,059$ y $B=-0,087$, respectivamente), mientras que el número de horas semanales dedicadas a las obligaciones escolares se asociaron positivamente con la satisfacción con la vida ( $B=$.052). Además, los estudiantes que dedicaron mayor tiempo a conductas sedentarias frente a un televisor u ordenador tenían un riesgo significativamente mayor de baja satisfacción con la vida $(\mathrm{OR}=1.276$ y $\mathrm{OR}=1.317$, respectivamente). Por el contrario, los adolescentes que dedicaron más tiempo a las obligaciones escolares mostraron un riesgo significativamente menor de baja satisfacción con la vida $(\mathrm{OR}=.809)$. Estos resultados en estudiantes españoles ayudan a confirmar la relación negativa del abuso de TV y PC con la satisfacción con la vida de los adolescentes. Nuestros hallazgos también sugieren que las respuestas emocionales positivas durante la realización de las obligaciones escolares aumentan la satisfacción con la vida, mientras que las emociones negativas durante este comportamiento no la dañan significativamente. En conclusión, la satisfacción con la vida podría mejorarse con menos 


\section{Egitania}

$s$ c i e $\Omega$ c i a

tiempo frente a la pantalla, pero no todas las conductas sedentarias le afectan por igual.

Palabras clave: tiempo de pantalla, sedentarismo, felicidad, deberes.

* Department of Physical Education, Faculty of Education Sciencies, University of Cádiz.

** Department of Physical Education, Faculty of Education Sciencies, University of Cádiz.

*** Facultad de Educación, Universidad de Zaragoza, Spain.

*** Departamento Deporte e Informática , Universidad Pablo de Olavide, Sevilla, Spain. 


\section{INTRODUCTION}

Subjective wellbeing is a multifactor construct to describe a specific condition beyond the mere absence of disease whose main component is life satisfaction or global life assessment (Pavot, Diener, Colvin, \& Sandvik, 1991). Longitudinal and cross-sectional studies have proven the importance of life satisfaction for teenage development, as it favors social relations and prevents unhealthy behaviors (Grao-Cruces et al., 2013; Nuviala et al., 2009; Valois, Zullig, Huebner, \& Drane, 2004a). A positive association between physical activty (lannotti et al., 2009; Paupério, Corte-Real, Dias, \& Fonseca, 2012; Valois, Zullig, Huebner, \& Drane 2004b), physical fitness (Borrás, Vidal, Ponseti, Cantallops, \& Palou, 2011; Grao-Cruces, Fernández-Martínez, \& Nuviala, 2014), and life satisfaction in teenagers has also been suggested (lannotti et al., 2009; Paupério et al., 2012; Valois et al., 2004b), while sedentary behaviors seem to have a negative influence on psychological wellbeing within this age range (lannotti et al., 2009). Although previous studies that examined the association between sedentary time and life satisfaction were limited only to sedentary activities in front of a screen (TV and/ or PC).

We are not aware of the existence of studies that examined the association between different sedentary behaviors and life satisfaction in a representative sample of adolescents in Andalusia (southern Spain). Based on the foregoing, the aim of this study was analyzing the association of sedentary behaviors with life satisfaction in Andalusian adolescents.

\section{METHODS}

\section{PARTICIPANTS}

A total of 1897 healthy Andalusian adolescents (13.88 \pm 1.29 years, 12-16 years; body mass index (BMI): $22.23 \pm 4.45 \mathrm{~kg} / \mathrm{m} 2)$, of whom 956 were boys and 941 girls, participated in this work. The sample was randomized among a total number of 20 centers of the eight Andalusian provinces. 


\section{MEASURES}

Weight and height were measured with light clothes and barefoot. Weight was measure using the scale TANITA BC-420-S class III (TANITA Corporation Inc., Arlington Heights, IL, USA). Height was measured using stadiometer SECA 214 (SECA Ltd., Hamburg, Germany). Sedentary behaviors (TV, PC and homework), and life satisfaction were assessed by the following questionnaires (average completion time $15 \mathrm{~min}$ ), respectively:

Health Behavior in School-aged Children $\square \mathrm{HBSC}$ questionnaire (Ministry of Health, Social Policy and Equality of Spanish Government, 2011). Adolescents indicated the hours a day watching TV on weekdays and at weekends, using PC on weekdays and at weekends, and doing their homework on weekdays and at weekends. The scale was the same for the six items [ 1 = no time, 2 = half an hour, 3 = one hour, 4 = two hours, ( ), and $9=$ seven hours]. A weighted average (in proportion to the seven days of the week) between the two items of each of these sedentary behaviors was used to dichotomize as high (5-9) and low (1-4) sedentary levels. The internal consistency of the items of sedentary behaviors was acceptable (Cronbach's $\alpha=.721$ for TV; .745 for PC, and .719 for the homework questions).

Satisfaction With Life Scale -SWLS- [Spanish version by Atienza, Pons, Balaguer, and García-Merita (2000)]. This scale comprises five questions, rated on a Likert scale ranging from 1 (totally disagree) to 5 (totally agree). The end result was dichotomized as very happy (21-25) or unhappy (5-20). The scale showed adequate reliability in terms of internal consistency in our sample (Cronbach's $\alpha=$.824).

\section{PROCEDURES}

Data were taken in the school year 2011-2012, from September to November. Teenagers, parents, teachers and principals of the participating centers were informed on the nature and objectives of the study at a meeting where informed consent from parents and adolescents was required. The work meets the highest standards of safety and ethics, the laws of the country where they were performed and the ethical stan- 
dards established for this type of study at the University of the authors. It was developed following the ethical guidelines of the current Declaration of Helsinki.

\section{STATISTICAL ANALYSIS}

IBM SPSS Statistics 21.0 for Windows (IBM Software Group, Chicago, IL, USA) was used to perform the analysis. Confidence level was established at 95\% ( $\mathrm{P}<$.05). Comparisons between genders of the anthropometric measurements, sedentary activities, and life satisfaction were performed using Student T test for independent samples. The association of physical activity and sedentarism with life satisfaction was examined by linear regression analysis. Moreover, binary logistic regression analysis was completed to study the association between high sedentarism levels (>2 hours/day of TV watching, PC using or homework) and life satisfaction (very happy [reference] vs. scarcely happy). All analyses were performed jointly for boys and girls, and all models were adjusted by age, gender and BMl.

\section{RESULTS}

Boys reported significantly higher BMl, and life satisfaction than girls, while females devoted more time to homework (Table 1).

Table 1. Mean (M) a standard deviation (SD) for anthropometric measures, TV, PC and homework time, and life satisfaction.

\begin{tabular}{|c|c|c|c|c|c|c|c|}
\hline & \multicolumn{3}{|c|}{ BOYS (956) } & \multicolumn{3}{c|}{ GIRLS (941) } & P \\
\hline & N & M & SD & N & M & SD & .097 \\
\hline AGE (YEARS) & 956 & 13.93 & $(1.30)$ & 941 & 13.84 & $(1.28)$ & $<.001$ \\
\hline WEIGHT (KG) & 956 & 61.92 & $(15.48)$ & 941 & 55.29 & $(12.17)$ & $<.001$ \\
\hline HEIGHT (M) & 956 & 1.65 & $(.09)$ & 941 & 1.58 & $(.06)$ & .002 \\
\hline BMI (KG/M2) & 956 & 22.70 & $(4.64)$ & 941 & 22.02 & $(4.23)$ & .627 \\
\hline TV (HOURS/DAY) & 956 & 2.24 & $(1.37)$ & 941 & 2.27 & $(1.31)$ & .147 \\
\hline PC (HOURS/DAY) & 956 & 2.04 & $(1.54)$ & 941 & 2.14 & $(1.56)$ & $<.001$ \\
\hline HOMEWORK (HOURS/ & 956 & 1.66 & $(1.14)$ & 941 & 2.09 & $(1.11)$ & \\
\hline DAY) & & & & & & & \\
\hline
\end{tabular}


Table 2 reports association between sedentary behaviours and life satisfaction. The time of TV watching and PC use were negatively associated to life satisfaction ( $B=-.059$ and $B=-.087$, respectively) while the number of weekly hours devoted to homework was positively associated to life satisfaction ( $B=.052)$.

Table 2. Standardized regression coefficients (B) showing the association between sedentary behaviors (TV, PC and homework) and life satisfaction in adolescents."

\begin{tabular}{|c|c|c|c|}
\hline & N & SS & P \\
\hline TV & & & \\
\hline LIFE SATISFACTION & 1897 & -.059 & .011 \\
\hline PC & & & \\
\hline LIFE SATISFACTION & 1897 & -.087 & $<.001$ \\
\hline HOMEWORK & & & .029 \\
\hline LIFE SATISFACTION & 1897 & .052 & \\
\hline
\end{tabular}

* All analyses were adjusted by age, gender and BML.

The results of the logistic regression analysis showed that teenagers who devoted greater time to sedentary activities (TV or PC) had significantly greater risk of low life satisfaction $(\mathrm{OR}=1.276$ and $\mathrm{OR}=1.317$, respectively). On the contrary, the teenagers who devoted more time to homework showed significantly lower risk of low life satisfaction (OR = .809) (see Table 3).

Table 3. Odd ratio (OR) and $95 \%$ confidence interval $(\mathrm{Cl})$ for low weekly physical activity level ( $\leq 4$ days a week of less than 1 hour of moderate-to-vigorous physical activity) and high sedentarism level ( $>2$ hours/day for TV, PC and homework, respectively) with lower life satisfaction."

\begin{tabular}{|c|c|c|c|c|c|}
\hline & & $N$ & $P$ & OR & $95 \% \mathrm{Cl}$ \\
\hline TV & & & & & \\
\hline LIFE SATISFACTION & $\begin{array}{c}\text { VERY } \\
\text { HAPPY }\end{array}$ & 862 & & 1 & REFERENT \\
\hline LOWER & 1035 & .010 & 1.276 & $1.060-1.535$ \\
\hline PIFE SATISFACTION & $\begin{array}{c}\text { VERY } \\
\text { HAPPY }\end{array}$ & 862 & & 1 & REFERENT \\
\hline
\end{tabular}




\begin{tabular}{|c|c|c|c|c|c|}
\hline & LOWER & 1035 & .004 & 1.317 & $1.090-1.591$ \\
\hline HOMEWORK & & & & & REFERENT \\
\hline LIFE SATISFACTION & $\begin{array}{c}\text { VERY } \\
\text { HAPPY }\end{array}$ & 862 & & 1 & $.662-.989$ \\
\hline & LOWER & 1035 & .038 & .809 & \\
\hline
\end{tabular}

*ORs were adjusted by gender, age and BMI.

\section{DISCUSSION}

The aim of this study is to examine the association between sedentary behaviors and life satisfaction in adolescents. Results report that Andalusian teenagers with high sedentarism in front of a screen (TV or PC) show higher risk of poor life satisfaction. Nevertheless, these associations do not appear when sedentarism is devoted to homework.

We found low life satisfaction in those who devoted longer daily time to TV and PC. Similar results were reported by lannotti et al. (2009), who concluded that sedentary behaviors in teenagers have a negative impact on psychological wellbeing. Previous findings were proved on 2291 US teenagers when the existence of a direct relation between these sedentary activities and depression in teenagers was confirmed (Katon et al., 2010), as well as on 5003 urban Chinese teenagers, who reported association between frequent and abundant TV watching and depressive symptoms and anxiety (Cao et al., 2011). Therefore, our results on Andalusian teenagers help to confirm the negative relationship of TV and PC abuse with life satisfaction in teenagers. However, not every kind of sedentarism has the same impact on life satisfaction. We found that sedentary time devoted to homework by teenagers is associated to lower risk of life dissatisfaction. Positive emotional responses during homework completion seem to increase life satisfaction, while negative emotions during this activity do not significantly damage life satisfaction in teenager (Lipnevich, MacCann, Bertling, Naemi, \& Roberts, 2012). A limitation of this study was its cross-sectional nature, which does not allow inferences about causality. A second limitation was the lack of analysis of socio-cultural variables, which may explain some of the differences found. Another limitation was that sedentary behaviors, and life satisfaction were measured by self-administered questionnaires. It is possible that some questions in the questionnaires may have been 
misreported either intentionally or inadvertently by some adolescents. Nevertheless, intentionally misreporting was probably minimized by the fact that study participants completed the questions anonymously, and all questionnaires were reliable and valid.

\section{CONCLUSIONS}

In summary, the current study suggests that sedentary behaviors for leisure purposes (TV and PC) reduce life satisfaction. Nevertheless, our work also reveals the need to distinguish between screen time and sedentary time devoted to homework, as they show opposite association with life satisfaction.

\section{ACKNOWLEDGMENTS}

The authors gratefully acknowledge all participating teenagers for their collaboration.

\section{BIBLIOGRAPHY}

Acsm (2011). Quantity and quality of exercise for developing and maintaining cardiorespiratory, musculoskeletal, and neuromotor fitness in apparently healthy adults: guidance for prescribing exercise. Medicine \& science in sport \& exercise, 43(7), 1334- 1359.

Arslan, f. (2011). The effects of an eight-week step-aerobic dance exercise programme on body composition parameters in middle-aged sedentary obese women. International sport med journal, 12(4), 160-168.

Borg, g. A. V. (1982). Psychophysical bases of perceived exertion. Medicine and science in sports and exercise, 14(5), 377-381.

De angelis, m., vinciguerra, g., gasbarri, a., \& pacitti, c. (1998). Oxygen uptake, heart rate and blood lactate concentration during a normal training session of an aerobic dance class. European journal of applied physiology and occupational physiology, 78(2), 121-127.

Desimone, g. (2012): acsm's resources for the group exercise instructor. Philadelphia, united states of america, lippincott williams \& wilkins.

Domene, p., moir, h., pummell, e., \& easton, c. (2016). Salsa dance and zumba 


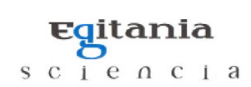

fitness: acute responses during community-based classes. Journal of sport and health science 5 (2016) 190-196.

Fox, s.m., naughton, i.p. \& haskell, w.l. (1971). Physical activity and the prevention of coronary heart disease. Annals of clinical research, 3, 404-432.

Grier, t. D., lloyd, I. K., walker, i. L., murray, t. D. (2002). Metabolic cost of aerobic dance bench stepping at varying cadences and bench heights. Journal of strength and conditioning research, 16 (2), 242-249.

Grossl, t., pires, c., silva, r. C. R., rosa, f., lucas, r., guglielmo, I. (2012). Perfil fisiológico de uma aula de body step. Rev. Educ. Fís/uem, 23(1), 87-96.

Jaywant, p.j. (20005): effect of aerobic dance on the body fat distribution and cardiovascular endurance in middle aged women. J. Exercise science and physiotherapy, 9 (1), 6-10.

Karvonen, m.j., kentala, k., \& musta, o. (1957). The effects of training heart rate: a longitudinal study. Annals of medicine and experimental biology, 35, 307-315. La torre, a., impellizzeri, f. M., rampinni, e., casanova, f., alberti, f., \& marcora, s. M. (2005). Cardiovascular responses to aerobic step dance sessions with and without appendicular overload. Journal of sports medicine and physical fitness, 45(3), 264- 269.

Laukkanen, r. M., kalaja, m. K., kalaja, s. P., holmala, e. B., paavolainen, I. M., tummavuori, m., ... rosko, h. K. (2001). Heart rate during aerobics classes in women with different previous experience of aerobics. European journal of applied physiology, 84(1-2), 64-68.

Luettgen, m., foster, c., doberstein, s., mikat, r., porcari, i. (2012). Zumba: is the "fitness-party" a good workout? Journal of sports science and medicine, 11, 357-358.

Martinovic, n. \& novaes, i. (2002). Respostas cardiovasculares e metabólica do step training em diferentes alturas de plataforma. Atividade física e saúde, 7 (2), 5- 11.

Reiner, m., niermann, c., jekauc, d., \& woll, a. (2013). Long-term health benefits of physical activity--a systematic review of longitudinal studies. Bmc public health, 13(1), 813.

Swain, d. P. (2000). Energy cost calculations for exercise prescription: an update. Sports medicine (auckland, n.z.), 30(1), 17-22.

Zaletel, p., furjan- mandié, g., zagorc, m. (2009). Differences in heart rate and lactate levels at three different workloads in step aerobics. Kinesiology, 41, 97 104.

Zar, i (2010): biostatistical analysis. 5th ed. New jersey, united states of america. Pearson printice hall. 